упругодеформационного воздействия / О.А. Серенко, У.А. Мурадова, И.Б. Мешков, Е.С. Оболонкова, С.Н. Зеленцкий, А.М. Музафаров // Каучук и резина. - 2008. - №3. C. 24-27.

2. Василовская Г.В., Иванова Л.А. Повышение долговечности асфальтобетона путем модификации вяжущего полимерными добавками / Г.В. Василовская, Л.А. Иванова // Труды НГАСУ. Современные строительные материалы и ресурсосберегающие технологии. - Новосибирск: НГАСУ, 2003. - Т .6, - №2 (23). - С. 203-207.

3. Колодезников К.Е. Цеолитоносные провинции востока Сибирской платформы / К.Е. Колодезников. - Якутск: ЯФ изд- ва СО РАН, 2003. - 224 с.

4. Христофорова А.А., Соколова М.Д. Механоактивационный способ обработки измельченных вулканизатов / А.А. Христофорова, М.Д. Соколова // Химия в интересах устойчивого развития. - 2009. - № 4. - С. 435-438.

\title{
Технологический анализ эффективности работы очистных сооружений в условиях Крайнего Севера
}

\section{Степанов А.В., Тастыгина С.А., Тихонов А.В., магистранты, Северо-Восточный федеральный университет, 2. Якутск E-mail: sara_punk@mail.ru}

Научный руководитель: стариий преподаватель Константинова Т.И.

В данной работе исследуется анализ работы очистных сооружений г. Якутска, рассматриваются предполагаемые причины возникновения эвтрофикации и меры по их устранению. Цель заключается в изучении и улучшении качества работы существующих очистных сооружений путем внедрения современных технологических решений и адаптации их в условиях Крайнего севера.

В Якутске с каждым годом растёт водопотребление питьевой воды, поэтому увеличивается и количество сточных вод. После хозяйственного и промышленного использования эти воды загрязняются различными веществами и их нельзя сбрасывать в реку без глубокой предварительной очистки.

Механические очистные сооружения канализации г. Якутска в 2006 году заменены уникальной станцией биологической очистки сточных вод (СБОС) с мощностью 90 тыс. м3/сут, которая построена по первому строительному принципу с сохранением многолетней мерзлоты. Принята технология Кейптаунского университета, предусматривающая удаление азота и фосфора в биореакторе, которая размещена в отапливаемом и вентилируемом помещении. Согласно проекту сточная жидкость из ГНС поступает в камеру гашения напора, далее по трем каналам направляется в решетки.

Биореактор, куда поступает сточная жидкость после первичного отстойника, состоит из трех принципиально отличных зон. Первая зона - анаэробная, вторая - 
аноксидная, третья - аэробная. Биореактор предусматривает удаление из сточной жидкости растворимых и нерастворимых органических соединений азота и фосфора.

Вторичные отстойники, также как и первичные, оборудованы развитой системой лотков. Сбор ила производится механизмом, совмещающим основные свойства илососа и илоскребка.

Для доочистки сточных вод в проекте применены фильтры доочистки.

Внутри каналов распределения очищенной сточной воды расположены батареи, состоящих из ультрафиолетовых ламп, которые обеспечивают окончательное обеззараживание очищенных вод.

Загрязнение окружающей среды вызывает отравление водных горизонтов, эвтрофикацию поверхностных водных источников и другие, не менее сильные последствия, именно поэтому очистка сточных вод является очень важным пунктом к улучшению образовавшейся ситуации. Основными загрязнителями скорого цветения водоемов являются биогенные элементы (азот и фосфор). Если не проводить глубокую очистку стоков, не только по азоту и фосфору, а по всем важным загрязнителям, это чревато вызовом ухудшения вод, поступающих на станции водоподготовки ниже по течению и не только. Это и выдвинуло данную проблему вперед остальных.

Вызвано это, прежде всего, интенсивным антропогенным и техногенным воздействием на окружающую среду, основными источниками которого являются сточные воды населенных пунктов, агропромышленные объекты и химическая промышленность.

Проблема стала глобальной, если раньше основной задачей было удаление и окисление органических веществ, то сейчас это удаление азота и фосфора, усиливающие процесс эвтрофикации, выделяющие вредные токсины и вызывающие отравление у людей и животных при их концентрации выше ПДК (предельно допустимой концентрации).

На данный момент разработаны всевозможные сооружения, схемы и методы очистки стоков от азота и фосфора, и самым оптимальным и распространенным является биологический метод. Он обладает таким важным достоинством как деструкция органических загрязнений до углекислого газа и воды, так же в его аэробной зоне не развиваются болезнетворные бактерии. Образованные при этом осадки и избыточный активный ил используются в качестве удобрений и источника энергии. [1]

Так как очищенные сточные воды сбрасываются в реку Лена, а она в свою очередь является рыбохозяйственным водоемом первой категории, при выпуске сточных вод необходимо учитывать, что ПДК для всех категорий водоемов имеют различия, и регламентированы они приказом от 16.05.1974 N 1166-74 «Правила охраны поверхностных вод от загрязнения сточными водами».

Для изучения эффективности работы очистных сооружений, был проведен анализ по загрязняющим веществам на входе и на выходе из СБОС г. Якутска по сравнению с ПДК для рыбохозяйственного водоема первой категории. ПДК для данного вида водоема представлены в таблице 2, приказа от 28 апреля 1999 года N 96 «О рыбохозяйственных нормативах».

ОАО «Водоканал» г. Якутск предоставил необходимые отчеты по эксплуатационным и расчетным (проектным) данным которых были построены диаграммы 1-5 загрязняющих веществ на входе и выходе по сравнению с ПДК. 
Диаграмма 1. Фактическая глубина очистки по БПК

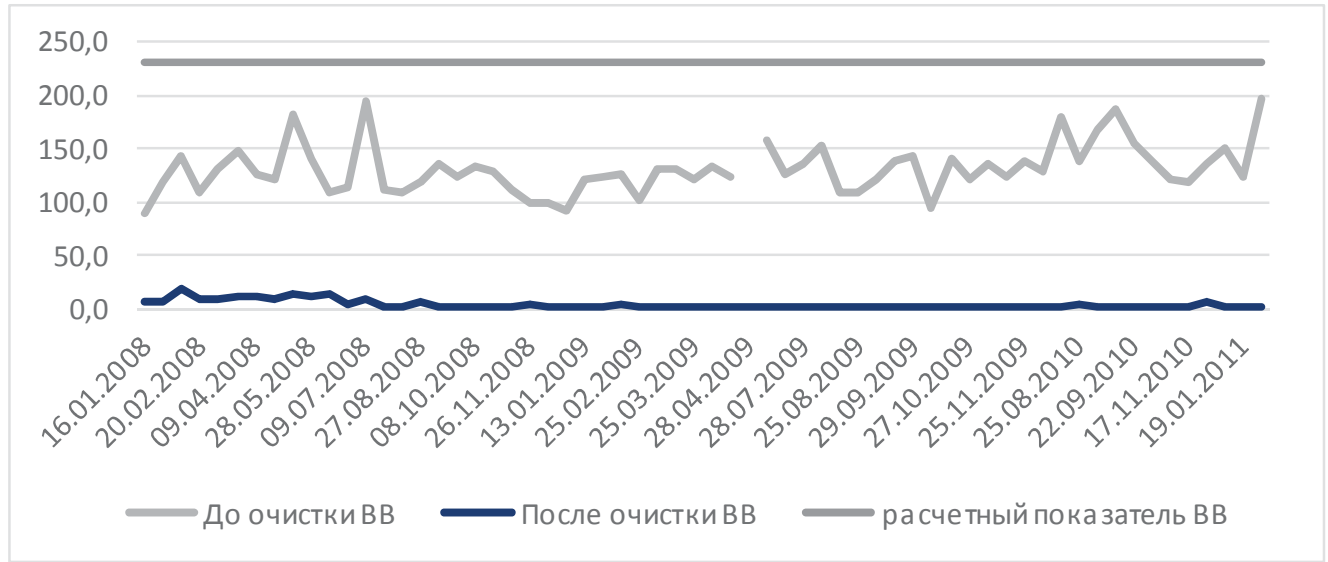

Диаграмма 2. Фактическая глубина очистки ВВ

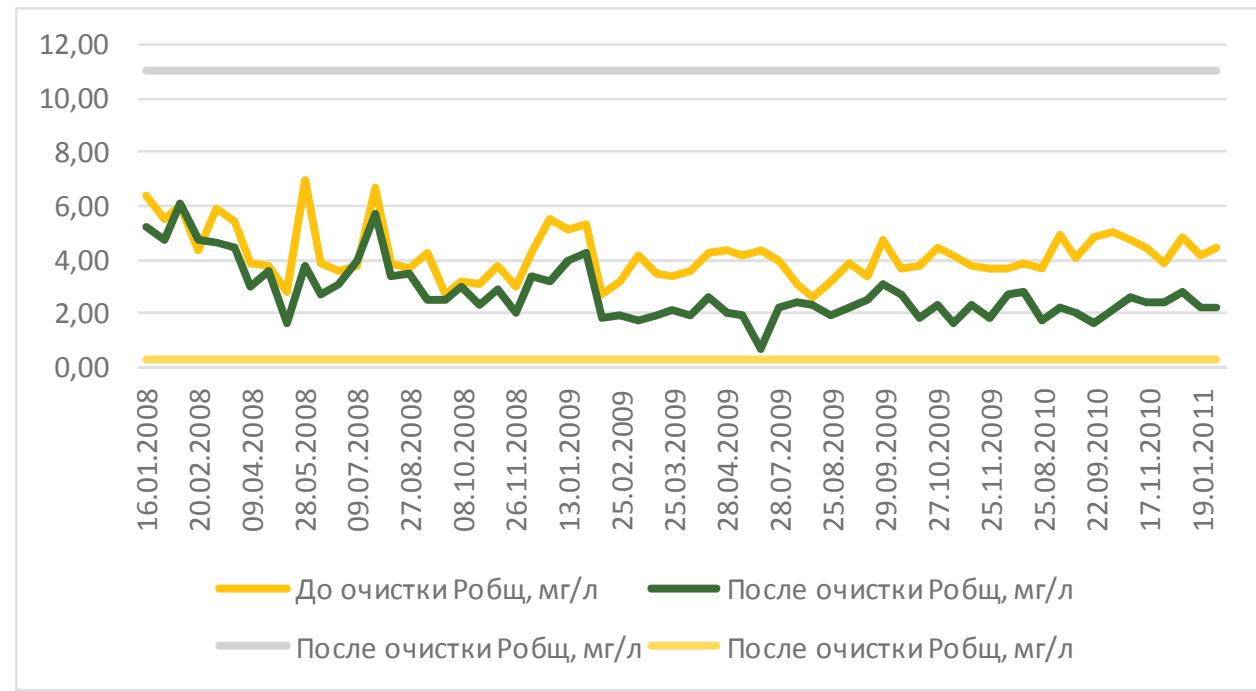

Диаграмма 3. Сравнение фактических и проектных показателей по общему содержанию фосфора 


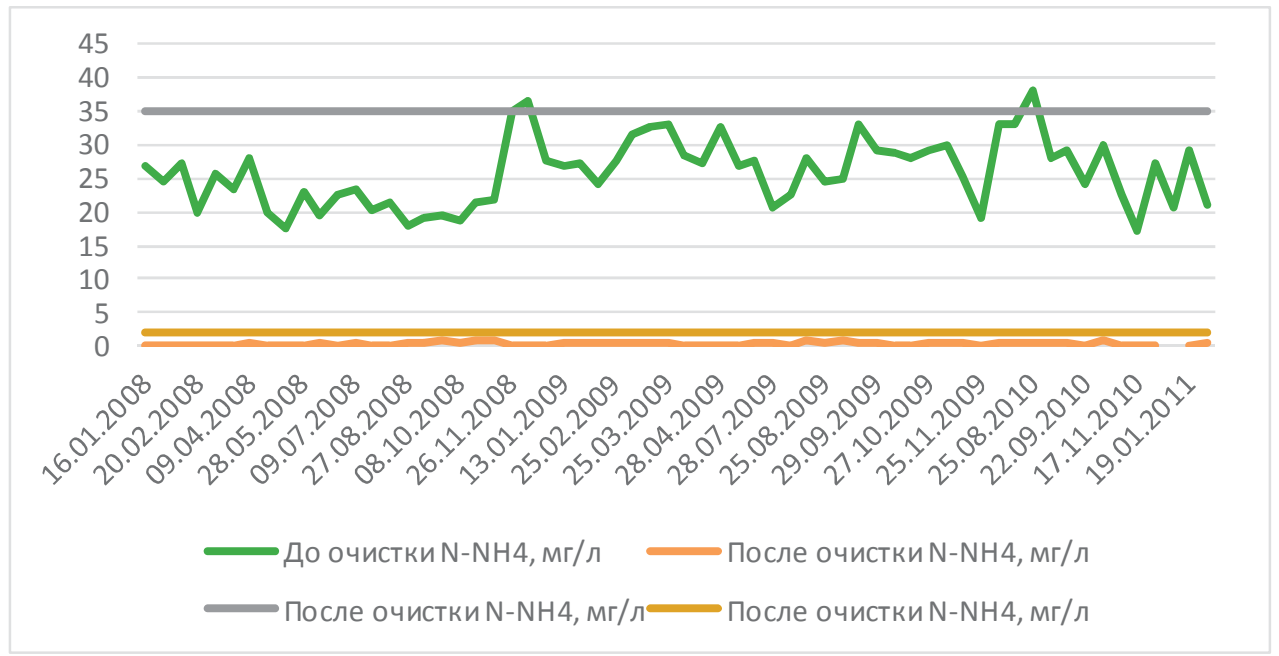

Диаграмма 4. Сравнение фактических и проектных показателей по азоту аммонийному

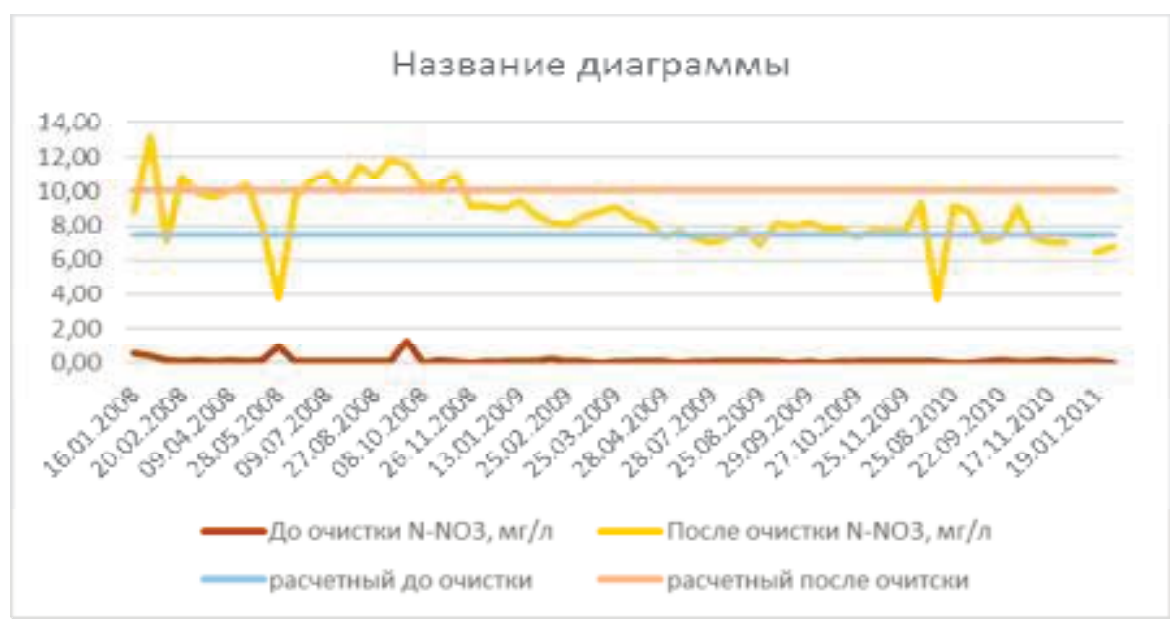

Диаграмма 5. Сравнение фактических и проектных показателей по азоту нитритов

Исходя из обработанных данных, диаграмм, очевидно, что очистные сооружения г. Якутска имеют ряд преимуществ и достигают ПДК (предельно допустимой концентрации) почти по всем показателям, но все же имеют недостаток, в том, что, очистке фактически не подвержен фосфор, который в свою очередь является лимитирующим показателем эвтрофикации водных объектов. В связи с этим, необходимо предусмотреть инновационные установки, предлагаемые иными регионами России, а может и другими странами, не забыв при этом адаптировать установки под суровые условия эксплуатации нашего региона. Очистные сооружения являются удовлетворяющими несмотря даже на тот факт, что фосфор не достигает ПДК. Это основывается на утверждении что для цветения водоема необходимо присутствие в высокой концентрации не только фосфора, но и азота.

Список литературы:

1. Сабирова Т.М., Сахаренко С.А., Оптимизация технологии биологической очистки сточных вод от азота // Химия и технология воды, 2000, №3. С. 326-333

2. Соловьева Е.А., Совершенствование технологии удаления азота и фосфора в комплексе по очистке сточных вод и обработке осадка: дис... докт.технич.наук. Санкт-Петербург, 2009. - С. 4-6. 
3. Разумовский Э.С., Залетова Н.А., Удаление биогенных элементов из городских сточных вод// Водоснабжение и санитарная техника, 1991, №6. С. 28-30.

\title{
Легкий бетон на основе гранулированного пеностекла для энергоэффективного строительства в условиях Арктики
}

\author{
Федоров В.И., инженер, \\ Северо-Восточный федеральный университет \\ E-mail: Elley-90@mail.ru \\ Научный руководитель: \\ д.т.н., профессор Местников А.Е.
}

Текущий рост производства промышленной продукции приводит к непрерывному увеличению потребления природных ресурсов, повышению расхода энергии, увеличению образующихся отходов и загрязнению окружающей среды. Современное строительное материаловедение тесно взаимосвязано с решением таких задач как повышение эффективности производства, снижение стоимости и трудоемкости технологических процессов, рациональному использованию материальных и энергетических ресурсов [4].

Разработка энергосберегающих строительных материалов является приоритетным направлением в строительной индустрии. Именно от свойств того или иного материала зависит надежность и долговечность строительных конструкций в целом. Одним из перспективных материалов, эксплуатируемых в суровых климатических условиях, являются разновидности ячеистых композитов на основе вяжущих гидратационного твердения [1]. Однако, учитывая положительный опыт использования данных материалов, выявлен ряд недостатков. В частности, относительно низкая прочность, которая обусловлена достаточной трудоемкостью получения оптимальной пористой структуры. В первую очередь это связано с необходимостью управлять большим количеством рецептурных и технологических факторов [4].

В связи с интенсивным увеличением строительства жилых и общественных зданий в Республике Саха (Якутия), возникает необходимость в наличии конкурентоспособного конструкционно-теплоизоляционного стенового материала способного выдерживать суровые климатические условия Крайнего Севера. В первую очередь материал должен обладать пониженной плотностью, низкой теплоповодностью, высокой морозостойкостью и хорошими показателями звукопоглощающения. С учетом отечественного и мирового опыта, одним из немногочисленных материалов, отвечающих вышерассмотренным требованиям, является легкий бетон на основе гранулированного пеностекла.

Образцы изготовлены согласно требованиям современных методик подбора состава бетона. Лабораторные испытания образцов выполнены на поверенных приборах испытательного центра «Якутск-Эксперт». Исследование структуры, определение качественных и количественных показателей образцов проведены на базе инновационно-технологического центра «Энергоэффективные строительные материалы». 